\title{
Gaming, guns and virtual gold
}

\section{John Gilbey savours a fast-paced technological thriller based at the intersection of the real world and the cyber-universe.}

I almost met Neal Stephenson once, at a conference in Silicon Valley, California. The author was sitting in a melee of scientists and technologists, but seemed oddly detached. If I had gone closer, I suspect I might have seen a flashing red 'Record' light in the corner of one eye as he absorbed his surroundings for future use.

Superb attention to detail is one defining characteristic of Stephenson's latest novel, $R E A M D E$. A thousand-page epic, the book hinges on the computer virus of the title, but offers a panorama of developing cybereconomies, online gaming, international terrorism and the flow of economic power from one culture to another. Stephenson frames the story as a series of intersections between the lives of techno-folk and the rest of the world, building a morass of foul-ups and misunderstandings that rings true.

The novel centres on 50-something loner Richard Forthrast, head of a successful online-gaming company called Corporation 9592. Already rich from a youth misspent backpacking drugs into the United States from Canada, Forthrast is an aficionado of online gaming - a passion that has led him to create T'Rain, now the dominant online role-play game of the age.

The REAMDE virus is designed to trap users of T'Rain by professional - if naive - hackers based in China. Once it infects a computer, the virus (with a nod to real examples) encrypts stored documents and demands a ransom. REAMDE adds a twist. The ransom must be paid in virtual gold within the game, from where it is collected by the virus writers in a form of 'gold-farming' - a means of working within games to convert virtual assets into actual cash value.

The scale of the infection disturbs the balance of the game: once word of huge

caches of gold gets out, every bandit and warlord of the virtual world seeks to make it his or her own - by force.

The degree of action in this multi-threaded plot puts most Hollywood blockbusters in the shade. Stephenson's narrative moves seamlessly between real and virtual worlds with impressive pace, and his descriptions of technology are accurate and believable. Aside from a couple of non-catalogue components introduced by an MI6 agent, there are no 'magic boxes' here. The novel is peopled with well-drawn characters such as Zula, Forthrast's software-engineer niece whose abduction sets the plot
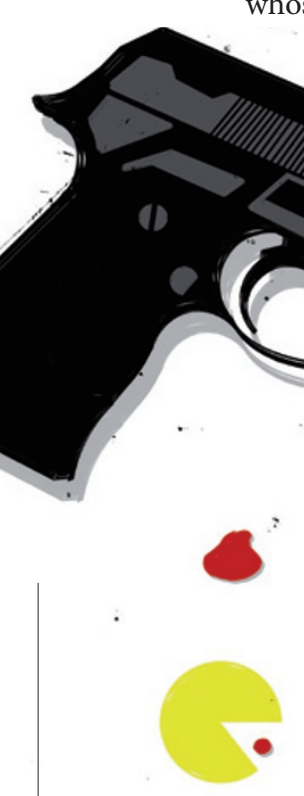

running, and Csongor, a Hungarian security specialist forced to survive on his wits. Add dangerously intelligent terrorists, darkly sinister state-security forces, grimy travel alternating with the height of luxury, and you find a novel in which a largely sympathetic cast of

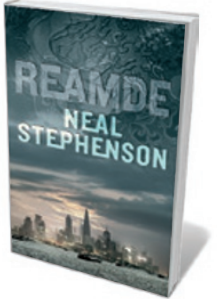

\section{REAMDE}

NEAL STEPHENSON Atlantic Books/William Morrow: 2011. 912 pp./1056 pp. $£ 18.99 / \$ 35$ characters is thrown in at the deep end of an extreme environment.

Unlike much of Stephenson's writing, $R E A M D E$ is set in the present. But it shares many aspects of his previous work, such as the highly regarded future-based novel Snow Crash: a strong-willed young heroine, dramatic and cinematic action, and lots of technology. His writing style has developed markedly since his early novels, in which gleeful descriptions of violent mayhem occasionally verged on the cartoonish. The opening sequence of REAMDE, for example, describes a fraught family reunion in rural Iowa - with various family members and hangers-on seeking approval for their shooting skills. The group's strong shared values and equally deep

divisions come across powerfully in a portrayal that is reminiscent of Annie Proulx or, to a degree, Garrison Keillor.

There is nothing routine about this masterly techno-thriller. REAMDE mixes elements of current concern in technology and in society. It makes clear how far we have moved towards a single global communications, entertainment and business environment, while still being bound by our own local cultural heritage. Stephenson demonstrates just how explosive that combination can be.

John Gilbey is in the Department of Computer Science, Aberystwyth University, Aberystwyth SY23 3DB, UK. e-mail:gilbey@bcs.org.uk

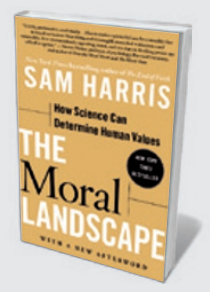

The Moral Landscape: How Science Can Determine Human Values Sam Harris (Free Press, 2011; \$15) Journalist Sam Harris argues that science can help us to understand moral values. Harris "eloquently counters the jaded pessimists who think that science has little to say about happiness", wrote reviewer Pascal Boyer (Nature 469, 297; 2011).

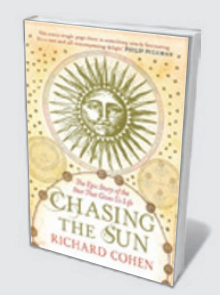

Chasing the Sun: The Epic Story of the Star That Gives Us Life Richard Cohen (Simon \& Schuster, 2011; £8.99) Richard Cohen examines why our star is studied and even worshipped. Douglas Gough noted that the book "paints a fascinating and far-reaching scene that incorporates nearly all aspects of solar phenomena" (Nature 468, 504-506; 2010). 